\title{
ON THE RELATIONSHIP BETWEEN REAL AND NOMINAL VARIABLES IN DEVELOPED COUNTRIES
}

\author{
Petr Duczynski*
}

\begin{abstract}
:
The paper examines money-output and price-output relations in developed countries between 1980 and 2005. We observe that declines in the nominal monetary base are connected with a moderately below-average behaviour of the real output. The same result applies for small positive growth rates of nominal M1 and M2. High growth rates of money are associated with the above-average product growth. We have some evidence that broader monetary aggregates are more closely associated with the real product than narrower monetary aggregates. As opposed to the money-output connection, we show that low inflation was accompanied by high product growth.
\end{abstract}

Keywords: consumer prices, developed countries, nominal monetary aggregates, real output

JEL classification: E31, E40, O40

\section{Introduction}

One of the most important and interesting problems in macroeconomics is the connection between real variables (such as the real product, industrial production, and unemployment) and nominal variables (such as the monetary aggregates and the price level). If money affects output, we call this phenomenon the non-neutrality of money. If, on the other hand, changes in money have no effects on output, then money is neutral. In economics most people believe that in the short run money is non-neutral, whereas in the long run it is neutral. In the long run, the real product stays at its potential level and the rate of unemployment equals the natural rate of unemployment. The potential product is mainly given by the factors of production and technology, and is not given by nominal variables.

The literature focusing on the relationship between real and nominal variables is extensive. There exist two fundamental studies: Friedman and Schwartz (1963) and Romer and Romer (1989). These studies are based on the narrative approach. Friedman and Schwartz study the monetary history in the United States between 1867 and 1960. Their analysis starts with the greenback period and ends with the discussion of the postwar rise in the velocity of money. The book shows the evolution of money, income, prices, and velocity. Friedman and Schwartz try to explain the fundamental reasons leading to the Great Depression in 1929-1933. Between 1920 and 1937, they find four periods

* Department of Economics, Faculty of Informatics and Management, University of Hradec Králové, Rokitanského 62, CZ - 50003 Hradec Králové (petr.duczynski@uhk.cz). I would like to thank anonymous PEP referees for helpful comments. 
of monetary shocks in which the monetary evolution was unusual under given economic conditions. They document the effects of money on the real economy. Romer and Romer (1989) somewhat differ from Friedman and Schwartz (1963) in the definition of a monetary shock. They regard as a monetary shock only situations in which the Fed attempted to reduce the product growth in order to decrease the inflation. They also provide a rigorous analysis for the postwar period. They show that monetary contractions had real effects.

Beside the narrative approach, there exists a statistical approach (see, for example, Attfield and Duck, 1983; Kormendi and Meguire, 1984; Duczynski, 2006). Attfield and Duck examine 11 countries and show that money affects the real output only if the money growth is unpredictable. Kormendi and Meguire study 47 countries and observe a short-run monetary non-neutrality and a long-run neutrality. Duczynski finds that correlations between the money growth and the product growth are small but statistically significantly positive in a broad sample of countries in the 1975-2000 period. Other relatively recent studies discussing the neutrality or the non-neutrality of money include Serletis and Koustas (2001), Lin and Yang (2003), and Portier (2004).

An important survey of the literature dealing with the relationship between real and nominal variables is provided in Walsh (2003, Chapter 1): McCandless and Weber (1995) study data from 110 countries in a 30-year period. They find that the correlation between inflation and the money growth rate is almost 1 , varying from 0.92 to 0.96 . They also conclude that there is no correlation between either money growth or inflation and the real output growth. Similarly, Geweke (1986) argues that for the United States, there is no long-run effect of money growth on real output growth. Other studies confirming the long-run neutrality of money include Boschen and Mills (1995) and Bullard and Keating (1995).

Monetary economics is also concerned with the relationship between interest rates, inflation, and money. The Fisher effect states that nominal interest rates should move together with inflation. Monnet and Weber (2001) focus on the period 1961 to 1998 in a sample of 31 countries. They observe a correlation of 0.87 between money growth and long-term interest rates. This is consistent with the Fisher effect. Mishkin (1992) examines the interest rate - inflation correlation in the U.S. data and also finds support for the Fisher effect. De Grauwe and Polan (2005) consider a sample of almost 160 countries over the previous 30 years. They find a strong positive relation between long-run inflation and the money growth rate. However, this relationship is weak in low-inflation countries.

Regarding short-run relationships between money and output, Walsh (2003, pp. 12-13) presents simple dynamic correlations from the U.S. quarterly data from 1967 to 2000 . The monetary base M0 is positively correlated with real GDP (the gross domestic product) at both leads and lags. In contrast, M2 is strongly positively correlated at lags but negatively correlated at leads.

From econometric techniques analysing the impact of money on output, we can mention St. Louis equations, Granger causality tests, and vector autoregressions (VAR). Friedman and Meiselman (1963) regressed nominal income on present and lagged values of autonomous expenditures, present and lagged values of monetary variables, and on other variables. They observed that there was a much more stable and statistically significant relationship between output and money than between output and their mea- 
sure of autonomous expenditures. Regressions of nominal income on money are often called St. Louis equations. Granger causality tests were proposed by Sims (1972). These tests are based on regressions of real income on lagged values of money, lagged values of income, and lagged values of other variables. Vector autoregressions (VAR) were introduced by Sims $(1972,1980)$. In this approach, a vector of output and a monetary variable is regressed on the first lag of this vector, multiplied by a matrix polynomial in the lag operator.

Concerning the Czech literature discussing monetary policy and its effects, we can mention, for example, Izák (1995) and Bulír (1996), who deal with selected problems of the endogeneity and the exogeneity of money. Frait and Komárek (2006) examine the concept of the neutrality and the superneutrality of money. Bruna (2007) focuses on the interest rate transmission mechanism of monetary policy. Šmídková and Bulír (2007) analyse the main communication tools of the Czech National Bank.

The paper is organized as follows. Section 2 presents some theoretical elements of the money supply and the money demand. Section 3 discusses the channels of monetary policy. Section 4 is devoted to the problem of endogenous money. Section 5 brings the main results, and Section 6 concludes.

\section{The Money Supply and the Demand for Money}

Before we turn to the empirics of the non-neutrality of money, we will briefly discuss some theoretical elements of the money supply and the money demand. It may be useful to add some theory to the empirics. The stock of money $(M)$ is the sum of currency $(C)$ and deposits $(D)$ of commercial banks:

$$
M=C+D
$$

In the equilibrium, the money stock equals the money supply $\left(M^{S}\right)$. We have different monetary aggregates (like $M 1$ or $M 2$ ) depending on what kinds of deposits are counted. Roughly speaking, $M 1$ includes demand deposits only, while $M 2$ includes demand deposits and time deposits. The monetary base (in the present paper denoted by $M 0$ ) is the sum of currency and reserves of commercial banks, $R$ :

$$
M 0=C+R
$$

By open market operations (OMO) the central bank can directly control MO. In this case the central bank sells or purchases government bonds. If, for example, the central bank purchases government bonds, $M O$ goes up. $M^{S}$ depends on $M O$ in the following way:

$$
M^{S}=m M 0,
$$

where $m=(C+D) /(C+R)=(C / D+1) /(C / D+R / D)$ is the money multiplier. Equation (3) is a traditional monetarist equation of the money supply. We directly observe that the money multiplier depends negatively on $R / D$. If we took a derivative of $m$ with respect to $C / D$, we would find that $m$ also depends negatively on $C / D$. For example, in the Great Depression in the United States in 1929-1933, people preferred currency to bank deposits and commercial banks held excess reserves. As a result, the money multiplier was low. 
In the equilibrium, the money supply $\left(M^{\mathrm{S}}\right)$ should equal the money demand $\left(M^{\mathrm{D}}\right)$ :

$$
M^{\mathrm{S}}=M^{\mathrm{D}}=M
$$

We can write the quantity equation:

$$
M V=P Y,
$$

where $V$ is the velocity of money, $P$ is the price level, and $Y$ is the real product. Hence, $P Y$ is the nominal product. Monetarism is the school of thought according to which $V$ is relatively stable and predictable. In this situation $M$ is the major determinant of $P Y$. In the short run $M$ influences both $P$ and $Y$, while in the long run $M$ influences only $P$. Monetarism is based on the quantity theory of money. This relatively old theory claims that also $Y$ is relatively stable, so that $P$ is directly proportional to $M$. Sometimes the quantity theory of money is called the quantity theory of prices.

The money demand, $M^{\mathrm{D}}$, is typically assumed to be a negative function of nominal interest rates and a positive function of output:

$$
M^{D} / P=\mathrm{f}(i, Y),
$$

where $i$ is the nominal interest rate. Although equation (6) has its roots in the neo-Keynesian economics, we adopt its form here. From the money demand equation and the quantity equation, the velocity of money can be written as

$$
V=P Y / M=Y / \mathrm{f}(i, Y) .
$$

Thus, for a given level of output, velocity depends positively on interest rates since the function $\mathrm{f}$ is decreasing in the interest rate.

\section{The Money Channels}

There exist a certain number of channels through which monetary policy can affect the real economy. These are mainly the interest rate channel, the exchange rate channel, the equity channel, the bank lending channel, and the balance sheet channel. A decrease in the money supply shifts the money supply curve in the money market to the left. This new supply curve intersects the money demand curve at a higher nominal interest rate. Some aggregate demand components - investment and consumption of durables - depend negatively on the real interest rate. Higher rates depress these components and the output level (the interest rate channel). Duczynski (2006) explains the effect of monetary policy on interest rates (the liquidity effect) based on the bond market instead of the money market and gets the same result. One problem with the interest rate channel is that investment and consumption should be sensitive to real interest rates instead of nominal interest rates, which are determined on the money market. Another problem is that sometimes interest rates may be high if we have monetary expansion because of high inflation. In an open economy with flexible exchange rates, the Mundell-Fleming model predicts that higher interest rates should lead to a financial capital inflow and an exchange rate appreciation. This pushes down net exports and output (the exchange rate chan- 
nel). Higher interest rates should also decrease prices of assets (securities and real estates). With lower wealth, households consume less and output goes down (the equity channel). A credit crunch can occur if we have monetary contraction - small firms are typically dependent on loans and a decline in the supply of credit can affect them negatively (the bank lending channel). A monetary contraction also decreases cash flows and the net worth of firms, which may magnify problems with asymmetric information in credit markets (the balance sheet channel).

\section{The Endogeneity of Money}

If we find a positive association between nominal money and real output, this does not necessarily mean that there is causality from money to output. Changes in money may endogenously respond to changes in output. For example, if there is a negative supply shock, then the output is low and prices are high. The central bank can accommodate the money supply - it tries to reduce inflation and decreases the money supply. As a result, there is a positive correlation of money and output - both are low at the same time. But money does not cause output in this case. King and Plosser (1984) discuss the problem of endogenous money in real business cycle models.

The narrative approach to monetary non-neutrality can better address the problem of monetary endogeneity than the statistical approach. Nevertheless, Duczynski (2006, p. 130) presents some advantages of the statistical approach. For this reason, the issue of monetary endogeneity might not be important extremely.

\section{The Results}

We consider all developed countries in the 1980-2005 period. The data source is the International Financial Statistics Yearbook $(2002,2007)$ of the International Monetary Fund. The given data are believed to be of high quality. Regarding the definition of developed countries, we follow the list presented in the International Financial Statistics Yearbook (industrial countries). The growth of the monetary base (reserve money, $\mathrm{MO}$ ) is under the code $14 \mathrm{x}$. The growth of $M 1$ (money) is under the code $34 \mathrm{x}$. The growth of M2 (money plus quasi money) is under the code $351 \mathrm{x}$. The growth of consumer prices is under the code $64 \mathrm{x}$. The growth of the real gross domestic product (GDP) is under the code $99 \mathrm{bp} \mathrm{x}$.

The principal research method is to consider certain intervals of the growth rates of monetary aggregates (or consumer prices) and to examine the growth rates of output in a given year $\left(g_{t}\right)$ and in the subsequent year $\left(g_{t+1}\right)$. This technique follows Duczynski (2004). Since output is a flow variable and monetary aggregates are stock variables (measured at the end of a year), $g_{t}$ precedes changes in money, while $g_{t+1}$ follows changes in money. If we, for example, observed that $g_{t+1}$ reacted more sensitively to declines in money than $g_{t}$, this would be some indication that money changes precede output changes.

For a given interval of the growth rate of a monetary aggregate (or consumer prices) we compute the average $g_{t}$ and $g_{t+1}$ for all observations. We compare these averages to long-run average growth rates of real output in developed countries in 1980-2005 and 1981-2006, respectively. These are equal to $2.53 \%$ and $2.61 \%$, respectively. Since we consider a sample of 23 developed countries, we have some advantage over studies fo- 
cusing on one country only or on a small number of countries: random effects existing in individual countries are averaged out in the present study. Despite the fact that the applied research technique is relatively simple, we can provide some useful information on the fundamental problem - the relationship between real and nominal variables. It is sometimes a good strategy to keep the analysis as simple as possible.

\section{Declines in Monetary Aggregates}

Table 1 presents the results for declines in the monetary base (MO), $M 1$, and $M 2$. Table 2 then shows the source data for declines in $M 1$. The average $g_{t}$ and $g_{t+1}$ are below the total long-run average for declines in $M 0$. Similarly, the average $g_{t+1}$ is below the total average for declines in $M 1$. For $M 0$ and $g_{t}$, this fact is marginally statistically significant, as measured by the t-statistic. For $M 0$ and $g_{t+1}$, and $M 1$ and $g_{t+1}$, this result is statistically significant. Mainly for $M O$ we have a robust result because of the relatively high number of observations. Thus, we have good evidence that money and output are positively connected. For $M 2$ this is, however, not confirmed due to a low number of observations.

Table 1

The Average Product Behaviour for Declines in Monetary Aggregates M0, M1, and M2

\begin{tabular}{|l|r|r|r|}
\hline & M0 & M1 & M2 \\
\hline $\boldsymbol{g}_{\boldsymbol{t}}$ & 2.17 & 2.73 & 2.68 \\
\hline $\boldsymbol{s}_{\boldsymbol{t}}$ & 1.83 & 2.38 & 2.50 \\
\hline $\boldsymbol{n}_{\boldsymbol{t}}$ & 94 & 27 & 18 \\
\hline $\boldsymbol{t}_{\boldsymbol{t}}$ & 1.91 & -0.44 & -0.25 \\
\hline $\boldsymbol{g}_{\boldsymbol{t}+\mathbf{1}}$ & 2.06 & 1.49 & 2.64 \\
\hline $\boldsymbol{s}_{\boldsymbol{t}+\mathbf{1}}$ & 2.09 & 2.47 & 2.40 \\
\hline $\boldsymbol{n}_{\boldsymbol{t}+\mathbf{1}}$ & 94 & 26 & 18 \\
\hline $\boldsymbol{t}_{\boldsymbol{t}+\mathbf{1}}$ & 2.55 & 2.31 & -0.05 \\
\hline
\end{tabular}

Notes: $g_{t}$ denotes the average product growth in the year of a monetary decline (in $\%$ ); $s_{t}$ is the corresponding standard deviation (in \%); $n_{t}$ is the number of observations; $t_{t}$ is the t-statistic testing the statistical significance of the difference of $g_{t}$ from the total average growth rate, $2.53 \% ; g_{t+1}$ denotes the average product growth in the year following a monetary decline, and $s_{t+1}, n_{t+1}$, and $t_{t+1}$ are variables analogous to $s_{t}, n_{t}$, and $t_{t} . t_{t+1}$ relates to the total average growth rate of $2.61 \%$.

Money changes precede output changes for $M 1$ and to some small extent for $M 0$ since the effect on $g_{t+1}$ is more important than the effect on $g_{t}$. The average of $g_{t}$ and $g_{t+1}$ is $2.12 \%$ for $M 0$ and $2.11 \%$ for $M 1$. Thus, the effect of $M O$ on output is comparable to the effect of $M 1$ on output. However, a smaller change in $M 1$ is sufficient to generate this effect - the average fall in $M O$ is $9.2 \%$, while the average decline in $M 1$ is only $2.4 \%$. This is evidence that $M 1$ (a broader aggregate) is more connected with output than $M 0$ (a narrower aggregate). 
Table 2

\section{Declines of $M 1$}

\begin{tabular}{|c|c|c|c|c|}
\hline country & year & $\Delta M 1 / M 1(\%)$ & $\mathrm{g}_{t}(\%)$ & $g_{t+1}(\%)$ \\
\hline Australia & 1982 & -0.2 & 0.7 & -0.6 \\
\hline Austria & 1981 & -2.5 & -0.1 & 1.9 \\
\hline Canada & 1981 & -0.5 & 3.7 & -3.2 \\
\hline \multirow[t]{2}{*}{ Denmark } & 1992 & -0.9 & 0.6 & $\mathrm{n} / \mathrm{a}$ \\
\hline & 1994 & -1.4 & 5.5 & 2.8 \\
\hline Germany & 1981 & -1.5 & 0.1 & -1.0 \\
\hline Greece & 2000 & -4.0 & 4.1 & 4.1 \\
\hline Iceland & 2001 & -2.0 & 3.9 & -0.1 \\
\hline \multirow[t]{3}{*}{ Ireland } & 1982 & -1.3 & 2.3 & -0.2 \\
\hline & 1991 & -1.7 & 1.9 & 3.3 \\
\hline & 1997 & -17.4 & 10.8 & 8.6 \\
\hline \multirow[t]{2}{*}{ Japan } & 1980 & -2.0 & 3.6 & 3.2 \\
\hline & 1983 & -0.1 & 2.3 & 3.8 \\
\hline Netherlands & 1981 & -2.4 & -1.5 & -1.1 \\
\hline New Zealand & 1996 & -4.5 & 3.1 & 2.6 \\
\hline Spain & 1992 & -2.0 & 0.7 & -1.2 \\
\hline \multirow[t]{8}{*}{ Switzerland } & 1980 & -0.1 & 4.4 & 1.6 \\
\hline & 1981 & -0.4 & 1.6 & -1.4 \\
\hline & 1985 & -2.5 & 3.4 & 1.6 \\
\hline & 1989 & -2.7 & 4.3 & 3.7 \\
\hline & 1990 & -1.6 & 3.7 & -0.8 \\
\hline & 1991 & -1.7 & -0.8 & -0.1 \\
\hline & 2000 & -2.1 & 3.0 & 1.3 \\
\hline & 2004 & -5.6 & 2.3 & 1.9 \\
\hline \multirow[t]{3}{*}{ United States } & 1995 & -0.9 & 2.7 & 3.6 \\
\hline & 2000 & -1.7 & 4.1 & 1.2 \\
\hline & 2005 & -0.9 & 3.2 & 3.3 \\
\hline
\end{tabular}

Note: In this table $g_{t}$ denotes the real output growth rate in the year of a monetary decline, while $g_{\mathrm{t}+1}$ denotes the real output growth rate in the subsequent year. This notation is analogous to the other tables, where we, however, work with averages across developed countries.

For the 5 observations with the largest decline in $M 0$, the average $g_{t}$ is $2.40 \%$ (standard deviation $1.08 \%$ ), and the average $g_{t+1}$ is $4.10 \%$ (standard deviation $2.68 \%$ ). For the 5 observations with the largest decline in $M 1$, the average $g_{t}$ is $4.92 \%$ (standard deviation $3.38 \%$ ), and the average $g_{t+1}$ is $4.18 \%$ (standard deviation $2.62 \%$ ). For the 5 cases with the greatest decline in $M 2$, the average $g_{t}$ is $3.22 \%$ (standard deviation $1.79 \%$ ), and the average $g_{t+1}$ is $1.78 \%$ (standard deviation $0.63 \%$ ). Except for $M 2$ and $g_{t+1}$, we have no evidence that large money declines are harmful for the output growth. It is likely that the size of the money decline is not important for the behaviour of real output. 


\section{Small Positive Growth of Money}

Table 3 shows the results for small positive growth rates of $M 0, M 1$, and $M 2$. We choose the interval of money growth rates between 0 and $5 \%$. We may justify this interval by the following consideration: For the largest economy - the United States, $M 1$ grew in the interval between 0 and $5 \%$ in $42 \%$ of cases. This is a high number. Therefore, it would not be appropriate to consider a broader interval, such as between 0 and $7.5 \%$. On the other hand, a narrower interval than between 0 and $5 \%$ would mean a low number of observations, which would leave the results less robust statistically.

Table 3

The Average Product Behaviour for Small Positive Growth Rates (between 0 and $5 \%$ ) of Monetary Aggregates

\begin{tabular}{|l|c|c|c|}
\hline & M0 & M1 & M2 \\
\hline $\boldsymbol{g}_{\boldsymbol{t}}$ & 2.41 & 2.18 & 1.80 \\
\hline $\boldsymbol{s}_{\boldsymbol{t}}$ & 1.94 & 2.14 & 1.83 \\
\hline $\boldsymbol{n}_{\boldsymbol{t}}$ & 119 & 81 & 118 \\
\hline $\boldsymbol{t}_{\boldsymbol{t}}$ & 0.67 & 1.47 & 4.33 \\
\hline $\boldsymbol{g}_{\boldsymbol{t}+\boldsymbol{1}}$ & 2.58 & 2.13 & 2.04 \\
\hline $\boldsymbol{s}_{\boldsymbol{t}+\mathbf{1}}$ & 2.13 & 1.79 & 1.90 \\
\hline $\boldsymbol{n}_{\boldsymbol{t}+\mathbf{1}}$ & 119 & 83 & 120 \\
\hline $\boldsymbol{t}_{\boldsymbol{t}+\mathbf{1}}$ & 0.15 & 2.44 & 3.29 \\
\hline
\end{tabular}

Note: The notation of variables follows the notation used in Table 1.

As indicated in Table 3, small growth rates of money are connected with below-average behaviour of output for $M 1$ and $M 2$. As measured by the t-statistics, the results are marginally statistically significant for $M 1$ and $g_{t}$, significant for $M 1$ and $g_{t+1}$, and strongly significant for $M 2$ and $g_{t}$ and $g_{t+1}$. Consequently, we have again some evidence that money and output are positively associated. For $M 0$, the connection between money and output is weak and insignificant. Thus, $M 1$ and $M 2$ (broader aggregates) are more strongly associated with output than $M 0$ (a narrower aggregate). For $M 2$ (a broader aggregate), the effects on output are somewhat more important than for MI (a narrower aggregate).

There exists only a very weak tendency of money changes to precede output changes for $M 1$ since the effect on $g_{t+1}$ is slightly more important than the effect on $g_{t}$. (We must compare these numbers with $2.53 \%$ for $g_{t}$ and $2.61 \%$ for $g_{t+1}$.) In comparison, this tendency is not at all observed for $M 2$.

\section{High Growth of Money}

Table 4 presents the results for the fast growth rates of $M 0, M 1$, and $M 2$ - above $15 \%$. The average product behaviour is above the total long-run average both for $\mathrm{g}_{t}$ and for $g_{t+1}$ for all of these aggregates. As measured by the t-statistics, the results are marginally statistically significant for $M 0$ and $g_{t}$ and $g_{t+1}$ and for $M 1$ and $g_{t+1}$, and significant for $M 1$ and $g_{t}$ and $M 2$ and $g_{t}$. The results are insignificant for $M 2$ and $g_{t+1}$. Thus, we have again 
good evidence that nominal money and real output are positively associated. Here the money changes do not precede output changes since the effects (as compared to the total long-run averages) on $g_{t+1}$ are not notably higher than the effects on $g_{t}$.

Table 4

The Average Product Behaviour for the Rapid Growth of Monetary Aggregates - above 15\%

\begin{tabular}{|l|r|r|r|}
\hline & M0 & M1 & M2 \\
\hline $\boldsymbol{g}_{\boldsymbol{t}}$ & 3.03 & 3.20 & 3.45 \\
\hline $\boldsymbol{s}_{\boldsymbol{t}}$ & 2.41 & 2.36 & 2.81 \\
\hline $\boldsymbol{n}_{\boldsymbol{t}}$ & 71 & 95 & 69 \\
\hline $\mathbf{t}_{\boldsymbol{t}}$ & -1.75 & -2.77 & -2.72 \\
\hline $\boldsymbol{g}_{\boldsymbol{t}+\mathbf{1}}$ & 3.13 & 3.05 & 2.94 \\
\hline $\boldsymbol{s}_{\boldsymbol{t}+\mathbf{1}}$ & 2.22 & 2.51 & 3.04 \\
\hline $\boldsymbol{n}_{\boldsymbol{t}+\mathbf{1}}$ & 71 & 94 & 70 \\
\hline $\boldsymbol{t}_{\boldsymbol{t}+\mathbf{1}}$ & -1.97 & -1.70 & -0.91 \\
\hline
\end{tabular}

Note: The notation of variables follows the notation used in Table 1.

The average growth for the fast growth of money is $35.8 \%$ for $M 0,24.0 \%$ for $M 1$, and $24.4 \%$ for $M 2 . M 1$ and $M 2$ (broader aggregates) are more strongly associated with the real product than $M O$ (a narrower aggregate) since the larger growth of $M O$ is necessary to generate a comparable effect on output.

For the 5 highest growth rates of $M 0$, the average $g_{t}$ is $3.36 \%$ (standard deviation $3.64 \%$ ). The average $g_{t+1}$ is $4.62 \%$ (standard deviation $1.58 \%$ ). For the 5 highest growth rates of $M 1$, the average $g_{t} i s 4.24 \%$ (standard deviation 4.64\%). The average $g_{t+1}$ is $3.62 \%$ (standard deviation $2.94 \%$ ). For the 5 highest growth rates of $M 2$, the average $g_{t}$ is $4.04 \%$ (standard deviation $4.66 \%$ ). The average $g_{t+1}$ is $4.10 \%$ (standard deviation $3.79 \%$ ). The averages of product growth rates are here somewhat higher than total averages in Table 4 . This is again some evidence that the product growth depends positively on the money growth.

For $M 1$ and $M 2$, we document the dependence of $g_{t}$ and $g_{t+1}$ on money growth rates in Figures 1-4 in the Appendix. These dependences are roughly positive except for the outlying observations. The outliers are the following: in Figure 1, Iceland, 1983, $g M 1=$ $78.2 \%$ and $g_{t}=-2.1 \%$; in Figure 2, Ireland, $1998, g M 1=25.2 \%$ and $g_{t+1}=10.9 \%$; in Figure 3, Ireland, 1997, $g M 2=19.5 \%$, and $g_{t}=10.8 \%$, and Iceland, $1983, g M 2=80.1 \%$, and $g_{t}=-2.1 \%$; in Figure 4, Ireland, 1996, $g M 2=15.6 \%$ and $g_{t+1}=10.8 \%$, Ireland, $1998, g M 2=17.8 \%$ and $g_{t+1}=10.9 \%$, and Iceland, 1982, $g M 2=70.3 \%$ and $g_{t+1}=$ $-2.1 \%$.

\section{Consumer Prices}

The connection between consumer price growth rates and output growth rates is documented in Table 5. For deflations, both $g_{t}$ and $g_{t+1}$ are below the total long-run average. This result is statistically significant for $g_{t}$ and marginally significant for $g_{t+1}$, but we have only a low number of observations to make this finding robust. For small positive 
inflations - below $2 \%$, we have a somewhat above-average behaviour of output both for $g_{t}$ and $g_{t+1}$. This observation is marginally statistically significant for $g_{t}$ and strongly significant for $g_{t+1}$. For higher inflations - above $5 \%$, the output growth is below average both for $g_{t}$ and $g_{t+1}$. This finding is statistically significant for $g_{t}$ and strongly significant for $g_{t+1}$. These results are relatively robust due to a high number of observations. Thus, we have some evidence that low positive inflation is probably good for the product growth. This evidence differs from the evidence concerning the monetary aggregates.

Table 5

The Average Product Behaviour for Declines in Consumer Prices, Small Inflation (between 0 and $2 \%$ ), and Higher Inflation (above $5 \%$ )

\begin{tabular}{|l|c|c|c|}
\hline & Deflation & Small inflation & Higher inflation \\
\hline $\boldsymbol{g}_{\boldsymbol{t}}$ & 1.83 & 2.78 & 2.13 \\
\hline $\boldsymbol{s}_{\boldsymbol{t}}$ & 1.20 & 1.96 & 2.34 \\
\hline $\boldsymbol{n}_{\boldsymbol{t}}$ & 12 & 140 & 170 \\
\hline $\boldsymbol{t}_{\boldsymbol{t}}$ & 2.02 & -1.51 & 2.23 \\
\hline $\boldsymbol{g}_{\boldsymbol{t}+\mathbf{1}}$ & 1.99 & 3.15 & 1.90 \\
\hline $\boldsymbol{s}_{\boldsymbol{t}+\mathbf{1}}$ & 1.21 & 2.06 & 2.36 \\
\hline $\boldsymbol{n}_{\boldsymbol{t}+\mathbf{1}}$ & 12 & 142 & 170 \\
\hline $\boldsymbol{t}_{\boldsymbol{t}+\mathbf{1}}$ & 1.77 & -3.12 & 3.92 \\
\hline
\end{tabular}

Note: The notation of variables follows the notation used in Table 1.

\section{Conclusion}

The relationship between real and nominal variables is a fundamental problem in macroeconomics. This paper examines money-output and price-output relations in developed countries in 1980-2005. We do not have a sufficient number of observations for declines in $M 2$ and to some extent in $M 1$, but we observe that declines in $M O$ (the monetary base) are associated with moderately low output growth. For declines in $M 1$, we observe a statistically significant association between money and subsequent output growth rates. For small positive growth rates of $M 1$ or $M 2$ we also get a positive association between money and output - the output growth is somewhat below average in this case and this effect is practically statistically significant. For small positive growth rates of $M 0$ we observe no effect on output. High growth rates of monetary aggregates $(M 0$, $M 1$, and M2) are connected with high product growth. This observation can be theoretically explained by the money channels discussed in Section 3 if we replace a monetary contraction with a monetary expansion. We have some evidence that broader monetary aggregates ( $M 2$ and $M 1)$ tend to be more closely associated with the real product than narrower monetary aggregates $(M 0$ and $M 1)$.

In particular, for a fall of $M 0$, the difference of the average growth of real output in the given year from the total long-run average in developed countries, $\Delta g_{t}$, is $-0.36 \%$, and the difference of the average growth of real output in the subsequent year from the total long-run average in developed countries, $\Delta g_{t+1}$, is $-0.55 \%$. For a fall of $M 1, \Delta g_{t}$ is $0.20 \%$, and $\Delta g_{t+1}$ is $-1.12 \%$. For a fall of $M 2, \Delta g_{t}$ is $0.15 \%$, and $\Delta g_{t+1}$ is $0.03 \%$. Here this result is not robust because of the low number of observations. For the small positive 
growth of $M 0, \Delta g_{t}$ is $-0.12 \%$, and $\Delta g_{t+1}$ is $-0.03 \%$. For the small positive growth of $M 1$, $\Delta g_{t}$ is $-0.35 \%$, and $\Delta g_{t+1}$ is $-0.48 \%$. For the small positive growth of $M 2, \Delta g_{t}$ is $-0.73 \%$, and $\Delta g_{t+1}$ is $-0.57 \%$. For the rapid growth of $M 0, \Delta g_{t}$ is $0.50 \%$, and $\Delta g_{t+1}$ is $0.52 \%$. For the rapid growth of $M 1, \Delta g_{t}$ is $0.67 \%$, and $\Delta g_{t+1}$ is $0.44 \%$. For the rapid growth of $M 2$, $\Delta g_{t}$ is $0.92 \%$, and $\Delta g_{t+1}$ is $0.33 \%$.

The possible influence of inflation on output stands in some contrast to the money-output relation. Periods of deflation are likely to be harmful for the product growth, but we had only a low number of observations to make this evidence stronger. We show that low inflation (below 2\%) was probably good for growth, while high inflation (above $5 \%$ ) was associated with low growth. In particular, for the low inflation, $\Delta g_{t}$ was $0.25 \%$, and $\Delta g_{t+1}$ was $0.54 \%$. For the high inflation, $\Delta g_{t}$ was $-0.40 \%$, and $\Delta g_{t+1}$ was $-0.71 \%$.

An important question is whether money changes precede output changes. This tendency was practically not observed for declines of $M O$ and $M 2$, but it was observed for declines of $M 1$. For small positive growth rates of $M 0, M 1$, and $M 2$, this tendency was practically not found out. For the rapid growth of money, money changes also did not precede output changes. Rather, the opposite was the case for M2.

\section{References}

Attfield, C. L. F., Duck, N. W. (1983), "The Influence of Unanticipated Money Growth on Real Output." Journal of Money, Credit, and Banking, 15 (4), pp. 442-454.

Boschen, J. F., Mills, L. O. (1995), "Tests of Long-run Neutrality Using Permanent Monetary and Real Shocks." Journal of Monetary Economics, 35 (1), pp. 25-44.

Brůna, K. (2007), "The Interest Rate Transmission Mechanism and the Management of Interest Margin in the Context of Czech National Bank Disinflation Policy." Politická ekonomie, 55 (6), pp. 829-851.

Buliř A. (1996), "Exogenita nabídky peněz: Některé pochybnosti o předchozím výzkumu (Exogeneity of Money Supply: Some Doubts on Earlier Research)." Finance a úvěr, 46 (1), pp. 37-43.

Bullard, J., Keating, J. W. (1995), "The Long-run Relationship between Inflation and Output in Postwar Economies." Journal of Monetary Economics, 36 (3), pp. 477-496.

De Grauwe, P., Polan, M. (2005), "Is Inflation Always and Everywhere a Monetary Phenomenon?" Scandinavian Journal of Economics, 107 (2), pp. 239-259.

Duczynski, P. (2004), "On the Non-neutrality of Money: Evidence from the 1990s." Prague Economic Papers, 13 (1), pp. 40-54.

Duczynski, P. (2006), "On the Correlations of Nominal Money and Real Output: A Simple Cross-country Analysis." Ekonomický časopis, 54 (2), pp. 126-138.

Frait, J., Komárek, L. (2006), "Half a Century of the World Money Development." Politická ekonomie, 54 (3), pp. 307-325.

Friedman, M., Meiselman, D. (1963), "The Relative Stability of Monetary Velocity and the Investment Multiplier in the United States: 1897-1958." In Stabilization Policies, Englewood Cliffs: Prentice Hall, pp. 165-268.

Friedman, M., Schwartz, A. J. (1963), A Monetary History of the United States, 1867-1960. Priceton: Princeton University Press.

Geweke, J. (1986), "The Superneutrality of Money in the United States: An Interpretation of the Evidence." Econometrica, 54 (1), pp. 1-22.

IMF (2002), International Financial Statistics Yearbook. Washington, DC: International Monetary Fund. IMF (2007), International Financial Statistics Yearbook, Washington, DC: International Monetary Fund. 
Izák, V. (1995), "Nabídka peněz - endogenní, nebo exogenní (Money Supply - Endogenous or Exogenous)." Finance a úvěr, 45 (5), pp. 291-303.

King, R. G., Plosser, C. I. (1984), "Money, Credit, and Prices in a Real Business Cycle." American Economic Review, 74 (3), pp. 363-380.

Kormendi, R. C., Meguire, P. G. (1984), "Cross-Regime Evidence of Macroeconomic Rationality." Journal of Political Economy, 92 (5), pp. 875-908.

Lin, C. C., Yang, C. C. (2003), "Tournaments, Minimum Wage, and Money Non-neutrality." Journal of Macroeconomics, 25 (4), pp. 481-489.

McCandless, G. T., Jr., Weber, W. E. (1995), "Some Monetary Facts." Federal Reserve Bank of Minneapolis Quarterly Review, 19 (3), pp. 2-11.

Mishkin, F. S. (1992), "Is the Fisher Effect for Real? A Reexamination of the Relationship between Inflation and Interest Rates." Journal of Monetary Economics, 30 (2), pp. 195-215.

Monnet, C., Weber, W. (2001), "Money and Interest Rates." Federal Reserve Bank of Minneapolis Quarterly Review, 25 (4), pp. 2-13.

Portier, F. (2004), "Menu Costs, (s,S) Rule, Imperfect Information and the Neutrality of Money." Economics Bulletin, 5 (7), pp. 1-8.

Romer, C. D., Romer, D. H. (1989), "Does Monetary Policy Matter? A New Test in the Spirit of Friedman and Schwartz." NBER Macroeconomics Annual, 4, pp. 121-170.

Serletis, A., Koustas, Z. (2001), "Monetary Aggregation and the Neutrality of Money." Economic Inquiry, 39 (1), pp. 124-138.

Sims, C. A. (1972), "Money, Income and Causality." American Economic Review, 62 (4), pp. 540-542.

Sims, C. A. (1980), "Comparison of Interwar and Postwar Business Cycles." American Economic Review, 70 (2), pp. 250-257.

Šmídková, K., Bulír, A. (2007), "Striving to be "Clearly Open" and "Crystal Clear": Monetary Policy Communication of the CNB." Finance a úvěr - Czech Journal of Economics and Finance, 57 (11-12), pp. 540-557.

Walsh, C. E. (2003), Monetary Theory and Policy. Cambridge, MA: MIT Press.

\section{APPENDIX:}

Figure 1:

The Dependence of the Real Output Growth on the Growth of Nominal M1 for the Rapid Growth of Money.

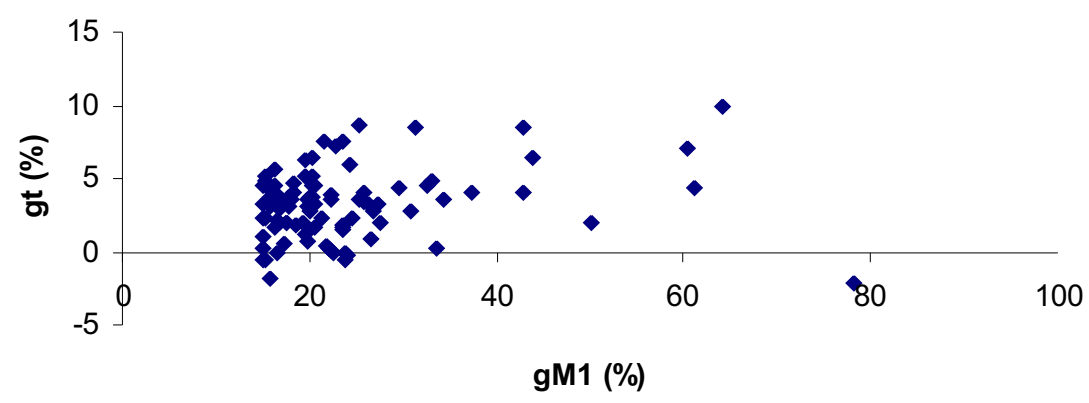


Figure 2:

The Dependence of the lead real Output Growth on the Growth of Nominal M1 for the Rapid Growth of Money.

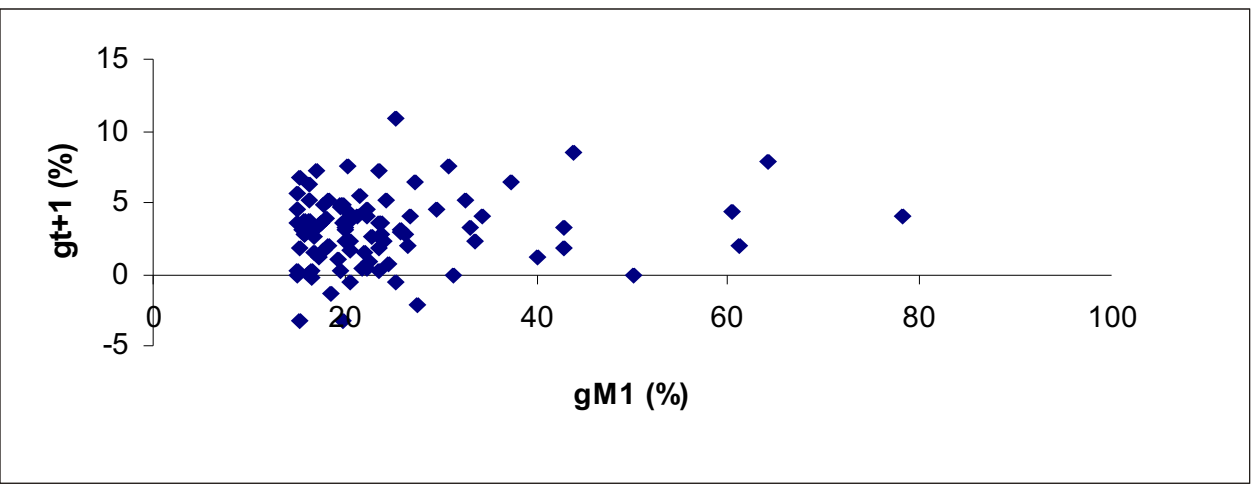

Figure 3:

The Dependence of the Real Output Growth on the Growth of Nominal M2 for the Rapid Growth of Money.

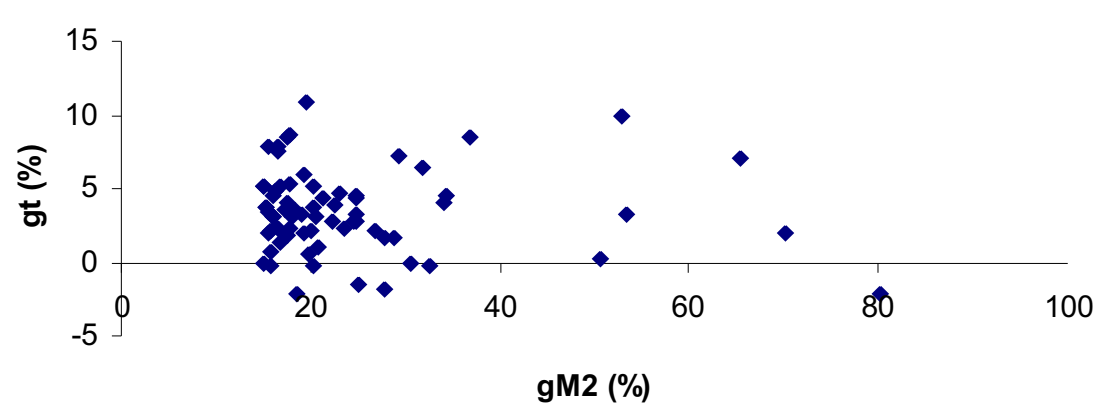

Figure 4:

The Dependence of the Lead Real Output Growth on the Growth of Nominal M2 for the Rapid Growth of Money.

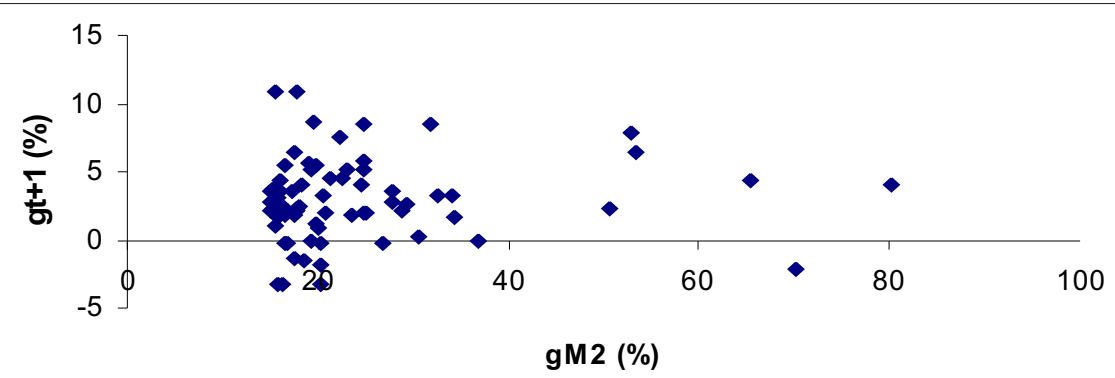

